\title{
The Destabilising Effects of Cryptocurrency Cybercriminality
}

\author{
Shaen Corbet $^{a}$, Douglas J. Cumming ${ }^{b}$, Brian M. Lucey $^{c, d, e}$, Maurice Peat $^{e}$, Samuel A. Vigne ${ }^{c}$ \\ ${ }^{a}$ DCU Business School, Dublin City University, Dublin 9, Ireland \\ ${ }^{b}$ FAU College of Business, Florida Atlantic University, Boca Raton, FL 33431, United States \\ ${ }^{c}$ Trinity Business School, Trinity College Dublin, Dublin 2, Ireland \\ ${ }^{d}$ Institute of Business Research, University of Economics Ho Chi Minh City, Ho Chi Minh City, Vietnam \\ e University of Sydney Business School, Sydney, New South Wales, Australia \\ *Corresponding Author: shaen.corbet@dcu.ie
}

\begin{abstract}
This paper investigates the financial market effects of recent cybercriminality in cryptocurrency markets. Hacking events are found to increase both the price volatility of the targeted cryptocurrency and broad cross-cryptocurrency correlations. Further, cybercrime events significantly reduce price discovery sourced within the hacked currency relative to other cryptocurrencies. Finally, abnormal returns in the hours prior to the cybercrime event, revert to zero when news is publicly announced.
\end{abstract}

Keywords: Price Volatility; Cryptocurrency; Hacking; Cybercrime; Bitcoin; GARCH.

\section{Introduction}

Cryptocurrencies have become popular because they enable efficient payment systems through a decentralised distributed ledger, which does not depend on a political process or governmental regulatory system. Our research attempts to develop our understanding of the widespread illicit behaviour that has been witnessed in cryptocurrency markets. With access to the public's credentials, hackers can steal electronic identities and move funds from legitimate accounts. Hackers may engage in phishing attacks in which the hacker steals credentials by faking the appearance of trustworthy sources. Hackers may further steal information through direct security breaches.

The continued evolution of cryptocurrencies and the underlying exchanges on which they trade has generated tremendous urgency to develop our understanding of a product that has been identified as a potential enhancement of and replacement for traditional cash as we know it. Urquhart [2016] was the first to examine the market efficiency of Bitcoin and found through a battery of tests that Bitcoin was inefficient, although it was becoming less inefficient over time. Much research 
continues to identify this asset class to contain exceptionally high levels of volatility when compared to more established counterparts (Corbet et al. [2019]). However, cryptocurrencies as a new asset class is not without its substantial issues, particularly that of the provision of a platform for criminality and, indeed, major cybercriminality events. While much debate surrounds the process in which this product can be regulated, there exists a wide variety of channels in which criminality can develop and thrive. Regulatory bodies and policy-makers alike have observed the growth of cryptocurrencies with a certain amount of scepticism, based on this growing potential for illegality and malpractice. Foley et al. [2019] estimate that around $\$ 76$ billion of illegal activity per year involve Bitcoin ( $46 \%$ of Bitcoin transactions). This is estimated to be in the same region of the U.S. and European markets for illegal drugs, and is identified as 'black e-commerce'. While the volatility of cryptocurrency price returns has been studied, for example, by Chu et al. [2017] and Phillip et al. [2018], the potential for market manipulation appears to have been broadly identified in cryptocurrency cross-correlations and market interdependencies. Griffins and Shams [2018] investigated as to whether Tether influenced Bitcoin and other cryptocurrency prices to find that purchases with Tether were timed following market downturns and resulted in significant increases in the price of Bitcoin. Such research has fine-tuned the focus of regulators, policy-makers and academics alike, broad trust in both cryptocurrencies and the exchanges on which they trade cannot be sustained with such significant questions of abnormality remaining unanswered. Developing understanding of these new products and how to mitigate cybercriminality and their illicit use is an exceptionally important task in order to validate their further use and development.

\section{Data}

We utilise data from the Bitfinex exchange at an 60-minute frequency for the eight most liquid cryptocurrencies throughout the period. The log return, $r_{t}=\ln \left(P_{t} / P_{t-1}\right)$ is then estimated for the period 1 September 2017 through midnight on 10 August 2018 for Bitcoin, Ethereum, Litecoin, Ripple, Stellar, Monero, Cardano and Bitcoin Cash. We considered the use of higher frequency data and even tick level data, however, the use of hourly data was found to be most effective from a methodological standpoint. The selection of Bitfinex as a source eliminates such fears presented by Alexander and Dakos [2019], who identified issues with data variation, widely dependent on the selected supplier. Table 1 presents the descriptive statistics of the selected cryptocurrencies. Stellar is the most volatile cryptocurrency with a variance of 0.00045 and standard deviation of 0.02111 . The largest one hour loss occurred in the market for Bitcoin Cash (-23.91\%), while the largest gain occurred in the market for Stellar $(+40.325 \%)$.

\section{Insert Tables 1 and 2 about here}


In Table 2 we have established a list of the seventeen largest cryptocurrency hacking events between September 2017 and August 2018. The list of hacking events includes a broad number of unique situations that targeted either the exchange on which cryptocurrencies trade, the blockchain supporting a specific cryptocurrency, or indeed the wallets of cryptocurrency investors. We have only included events that were determined as newsworthy if identified on mainstream broadsheet news sources on the LexisNexis database, Eikon and Bloomberg. The largest estimated loss from such cryptocurrency theft occurred on the $9^{\text {th }}$ of April 2018 when an alleged online scam, reportedly sourced in Vietnam, let to the generation of a false ICO led by the companies Ifan and Pincoin. The two firms are alleged to have misled approximately 32,000 investors and to have stolen in the region of $\$ 650$ million.

\section{Analysis}

After completing multiple specification tests, we utilise a multivariate $\operatorname{GARCH}(1,1)$ methodology (Bollerslev [1986]) to obtain volatility changes in the immediate aftermath of a major cybercrime incident relating to cryptocurrency markets. We mitigate international effects through the inclusion of the returns of traditional financial products in the mean equation of the $\operatorname{GARCH}(1,1)$ methodology of the following form:

$$
\begin{gathered}
R_{t}=a_{0}+\sum_{j=1}^{5} b_{j} R_{t-j}+b_{2} £ / \$_{t}+b_{3} V I X_{t}+b_{4} \text { Gold }_{t}+b_{5} S \& P_{t}+b_{6} \text { Oil }_{t}+\sum_{i=1}^{17} D_{i}+\varepsilon_{t} \\
\varepsilon_{t} \mid \Omega_{t} \sim i i d N\left(0, h_{t}\right) \\
h_{t}=\omega+\alpha_{1} h_{t-1}+\beta_{1} u_{t-1}^{2}
\end{gathered}
$$

$R_{t-j}$ represents the lagged value of cryptocurrency returns, $n$ hours before $R_{t}$ is observed. $b_{2} £ / \$_{t}$ represents the interaction between the selected cryptocurrency returns and $£ / \$$, while $b_{3} V I X_{t}$ represents the value of the VIX in the hour that the estimate $R_{t}$ was observed. Finally, $b_{5} S \& P_{t}$ and $b_{6} \mathrm{Oil}$ represent the relationship between cryptocurrency returns and the returns of the S\&P500 and oil as measured through the West Texas Intermediate (WTI). $\sum_{i=1}^{17} D_{i}$ is included to provide a coefficient relating to the included dummy variables indicating cybercriminality.

The multivariate-GARCH methodology, of which our results are presented in Table 3, incorporates past information through lagged cryptocurrency returns. Further, Table 4 provides robustness through the estimation of GARCH calculated volatility throughout the entire period in which we can denote episodes of cybercriminality. We observe that lagged returns are significant in all of our 
investigated cryptocurrencies with the exception of Ethereum. The results indicate that there are broad differences in the volatility responses of cryptocurrencies with evidence supporting significant instability generated within attacks on exchanges and ICO-fraud, both of which can be observed to be heavily dependent on perceptions of stability and financial safety. Any threat to such stability is found to lead widespread responses across a large number of cryptocurrencies rather than at the individual level. There is also evidence of cryptocurrency-specific volatility based on the market that has been directly targeted by such cybercrime. Such evidence is identified in the market for Bitcoin in hack $3(+0.0033)$, hack $4(-0.0031)$, hack $11(-0.0027)$ and for Ethereum during hack 8 $(0.0033)$.

\section{Insert Tables 3 and 4 about here}

Significant increases in the comovement and correlation of returns in traditional financial markets have been widely observed in periods of sharp financial crises (Forbes and Rigobon [2002]; Baig and Goldfajn [1999]). We utilise a DCC-GARCH methodology (Engle [2002]), to identify that there are lower estimates identified for smaller capitalisation cryptocurrencies when compared to the cross-correlations between their larger counterparts. This holds true not only for the dynamic correlations between smaller cryptocurrencies themselves, but also for the relationships between smaller and larger cryptocurrencies. Further, there is evidence of distinct phases of volatility that can be firmly attributed to key cybercrime events such as the bankruptcy of Youbit, the hacking of Nicehash and the scams relating to GainBitcoin and Ifan/Pincoin.

\section{Insert Table 5 and Figure 1 about here}

The combination of the above multivariate GARCH and DCC-GARCH analysis presents a number of interesting observations. Primarily, we can identify that there are sharp volatility responses in cryptocurrency markets during cybercrime events, which appear to be rationally targeted at cryptocurrencies directly involved and the broader sector of cryptocurrencies should the cybercrime event be systemically damaging. This is particularly evident during cybercrime events relating to theft directly based on wallets which proponents state is one of the key safety features of virtual currencies, and attacks on cryptocurrency exchanges that trade multiple cryptocurrencies. Further, we find evidence of broad comovement in cryptocurrency markets during periods of extreme stress and severe reputational damage which supports the hypotheses that these relatively youthful markets have developed to act somewhat similarly to traditional financial assets in time of crises.

We investigate changing dynamics in the information share and component share of price discovery before and after hacking events. There are two standard measures of price discovery commonly employed in the literature: the Hasbrouck [1995] Information Share (IS) and the Gonzalo and 
Granger [1995] Component Share (CS) approach. Hasbrouck [1995] demonstrates that the contribution of a price series to price discovery (the 'Information Share') can be measured by the proportion of the variance in the common efficient price innovations that is explained by innovations in that price series. A concise explanation of the selected methodology is presented in Corbet et al. [2018]. We present evidence of the changing components of price discovery in Figures 2 and 3 , which portray heat-maps representing the information share, the information leadership share and the component share of price discovery respectively.

\section{Insert Figures 2 and 3 about here}

These distinct differences in our information measures are of particular interest; information share demonstrates the contribution of a price series to price discovery which can be measured by the proportion of the variance in the common efficient price innovations while the component share presents the permanent and temporary components of price discovery, therefore the common efficient price and the efficient price caused by trading fractions. There is evidence to suggest that cybercriminality can distort these pricing relationships and can also influence large and small cryptocurrencies in a different manner. There is further evidence of differing responses based on the size of the cryptocurrencies analysed during hacks relating to cybercrime fraud. One of the most interesting results surrounds that of hack 2, relating to the theft of almost $\$ 431$ million in the cryptocurrency Tether on the $21^{\text {st }}$ of November 2017 where an attacker had stolen the funds directly from the Treasury wallet and subsequently moved them to an unauthorised account. While analysing this event, we must consider the work of Gandal et al. [2018] who identified the impact of suspicious trading activity on the Mt.Gox Bitcoin exchange theft when approximately 600,000 Bitcoins were attained. The authors demonstrated that the suspicious trading likely caused the spike in price in late 2013 from $\$ 150$ to $\$ 1,000$, most likely driven by one single actor.

With regards to cybercriminality based on the hacking of the exchanges on which cryptocurrencies trade, hack 3 and 4 related to the breaches at NiceHash and Youbit respectively. The scale of these cybercrime events resulted in widespread news coverage and despite little evidence of direct pricing volatility, there is substantial evidence of net transfer of information from smaller to larger cryptocurrencies through all three measures analysed, with particularly pronounced results evident in the the component share of information. The scale of this event appears to have provided somewhat of an informational equilibrium between large and small cryptocurrencies alike, as the shock echoed through the entire cryptocurrency sector. The distinct characteristics related to each cybercrime appears to have generated substantial reverberations within cryptocurrency markets due to the nature of the cybercrime event. While proponents of the new financial asset class continued to identify the safety of it's use as key feature of cryptocurrencies, these particular events exposed deep flaws within their structure and supported the argument against their credibility due to the 
ease in which assets could be stolen. These events all generate substantial flows of information through all measures from smaller cryptocurrencies to largest cryptocurrencies.

\section{Insert Figure 4 about here}

In Figure 4, we analyse the abnormal returns associated with each of the investigated hacking events. For brevity, we have only included the stated hacks. We find evidence of abnormal returns associated with the hacks of between $-2 \%$ to $-24 \%$, depending on the specific event. The abnormal returns are observed 4 hours prior to the actual hacking event and revert back to zero at the time and announcement of the hack. While the role of automated trading programs warrants particular investigation in these scenarios, we cannot eliminate the role of illicit behaviour as cryptocurrency markets absorb the broadly damaging news of such significant cybercrime events.

\section{Conclusion}

This research provides a number of novel findings related to our selected cryptocurrency markets. Primarily, there are significant differences identified in the volatility responses of cryptocurrencies to attacks on exchanges and ICO-fraud, both of which can be heavily dependent on perceptions of stability and financial safety. In a DCC-GARCH analysis, we observe that there are lower volatility estimates identified for smaller capitalisation cryptocurrencies when compared to the cross-correlations between their larger counterparts. We identify the largest sustained increase in cross-cryptocurrency correlations between the $6^{\text {th }}$ of December 2017 and the $13^{\text {th }}$ of January 2018 , incorporating a number of significant hacks in our sample. Peak cross-correlations occur on the $18^{\text {th }}$

of December 2017, indicative of a substantial loss of confidence in the cryptocurrency market during this time due to sustained internationally relayed coverage of multiple significant cybercrime events. The second distinct phase of elevated cross-correlations occurs during the period between the $4^{\text {th }}$ of March 2018 and the $9^{\text {th }}$ of April 2018 which represent the theft of approximately $\$ 300$ million during the multi-level-marketing scheme created by GainBitcoin and the ICO scam inspired by Ifan and Pincoin that resulted in the loss of $\$ 650$ million. Two distinct novel results are presented: 1) we find evidence of broad comovement in cryptocurrency markets during periods of extreme stress and severe reputational damage; and 2) these same relationships change substantially in the period after cryptocurrency cybercriminality, indicating that not only is the price volatility of these financial products directly influenced, but also the manner in which the information share, information leadership share and the component share of the price discovery is processed.

\section{Bibliography}

Alexander, C. and M. Dakos (2019). A critical investigation of cryptocurrency data and analysis. Available at SSRN. 
Baig, T. and I. Goldfajn (1999). Financial market contagion in the asian crisis. IMF staff papers 46(2), 167-195.

Bollerslev, T. (1986). Generalized autoregressive conditional heteroskedasticity. Journal of Econometrics $31(3), 307-327$.

Chu, J., S. Chan, S. Nadarajah, and J. Osterrieder (2017). Garch modelling of cryptocurrencies. Journal of Risk and Financial Management 10(4), 17.

Corbet, S., B. Lucey, M. Peat, and S. Vigne (2018). Bitcoin futures - what use are they? Economics Letters (172), 23-27.

Corbet, S., B. M. Lucey, A. Urquhart, and L. Yarovaya (2019). Cryptocurrencies as a financial asset: A systematic analysis. International Review of Financial Analysis 62, 182-199.

Engle, R. (2002). Dynamic conditional correlation: A simple class of multivariate generalized autoregressive conditional heteroskedasticity models. Journal of Business and Economic Statistics 20(3), 339-350.

Foley, S., J. R. Karlsen, and T. J. Putnins (2019). Sex, drugs, and bitcoin: How much illegal activity is financed through cryptocurrencies? The Review of Financial Studies 32(5), 1789-1853.

Forbes, K. J. and R. Rigobon (2002). No contagion, only interdependence: measuring stock market comovements. The Journal of Finance 57(5), 2223-2261.

Gandal, N., J. Hamrick, T. Moore, and T. Oberman (2018). Price manipulation in the bitcoin ecosystem. Journal of Monetary Economics 95, 86-96.

Gonzalo, J. and C. Granger (1995). Estimation of common long-memory components in cointegrated systems. Journal of Business 63 Economic Statistics 13(1), 27-35.

Griffins, J. and A. Shams (2018). Is bitcoin really un-tethered? Available at SSRN: https://ssrn.com/abstract=3195066 13 June 2018.

Hasbrouck, J. (1995). One security, many markets: Determining the contributions to price discovery. The Journal of Finance 50(4), 1175-1199.

Phillip, A., J. Chan, and S. Peiris (2018). A new look at cryptocurrencies. Economics Letters 163, 6-9.

Urquhart, A. (2016). The inefficiency of bitcoin. Economics Letters 148, 80-82. 
Table 1: Descriptive statistics of the traditional financial assets and cryptocurrencies

\begin{tabular}{lcccccccc}
\hline & Count & Mean & Variance & Std Dev & Skew & Kurt & Min & Max \\
\hline Bitcoin & 8,297 & 0.00011 & 0.00014 & 0.01195 & 0.48299 & 10.40750 & -0.10547 & 0.11889 \\
Ethereum & 8,297 & 0.00007 & 0.00018 & 0.01352 & 0.85312 & 15.16250 & -0.10905 & 0.15243 \\
Litecoin & 8,297 & 0.00011 & 0.00027 & 0.01657 & 1.48860 & 20.91631 & -0.12945 & 0.23656 \\
Ripple & 8,297 & 0.00020 & 0.00038 & 0.01954 & 2.37126 & 34.32370 & -0.16514 & 0.30347 \\
Stellar & 8,297 & 0.00046 & 0.00045 & 0.02111 & 2.99377 & 47.85589 & -0.14332 & 0.40325 \\
Monero & 8,297 & 0.00010 & 0.00029 & 0.01713 & 0.34831 & 8.26498 & -0.12667 & 0.18751 \\
Bitcoin Cash & 8,297 & 0.00019 & 0.00039 & 0.01981 & 0.69729 & 16.24494 & -0.23913 & 0.27164 \\
Cardano & 7,376 & 0.00035 & 0.00035 & 0.01859 & 2.44642 & 30.14793 & -0.17087 & 0.31692 \\
\hline \hline
\end{tabular}

Note: Our selected cryptocurrencies represent the eight largest by market capitalisation during the period in which data was collected, sampled at 60-minute intervals, for the period from midnight on 1 September 2017 through midnight on 10 August 2018. 
Table 2: Cryptocurrency hacking events used to investigate the differences in price volatility and discover

\begin{tabular}{|c|c|c|c|c|c|}
\hline Hack & Date & Time & Amount & Market & Description \\
\hline 1 & $07-$ Nov-17 & $11: 51$ & $\$ 280.0 \mathrm{~m}$ & Ethereum & $\begin{array}{l}\text { A user playing with the Parity multisig wallet library con- } \\
\text { tract triggered its kill function, effectively freezing the } \\
\text { funds. }\end{array}$ \\
\hline 2 & 21-Nov-17 & $04: 15$ & $\$ 30.0 \mathrm{~m}$ & Tether & $\begin{array}{l}\text { Tether stated that } \$ 30,950,010 \text { USDT was sent to an } \\
\text { unauthorized bitcoin address. }\end{array}$ \\
\hline 3 & 06-Dec-17 & $10: 45$ & $\$ 64.0 \mathrm{~m}$ & Bitcoin & Service breach and hack at NiceHash. \\
\hline 4 & 18-Dec-17 & $21: 35$ & $\$ 37.0 \mathrm{~m}$ & Bitcoin & $\begin{array}{l}\text { A message on Youbit's official website stated that, at } \\
\text { around } 4: 34 \text { a.m. local time, an external hack resulted } \\
\text { in the loss of 'about } 17 \% \text { of total assets.' }\end{array}$ \\
\hline 5 & 13-Jan-18 & $12: 00$ & $\$ 0.4 \mathrm{~m}$ & Stellar & $\begin{array}{l}\text { A DNS hijack has led to hackers withdrawing } \$ 400,000 \\
\text { worth of Stellar Lumen (XLM) coins from wallets hosted } \\
\text { by Blackwallet.co without user permission. }\end{array}$ \\
\hline 6 & 26-Jan-18 & $15: 00$ & $\$ 532.6 \mathrm{~m}$ & NEM & $\begin{array}{l}\text { On } 26 \text { Jan, Coincheck suspended all deposits in NEM on } \\
\text { their exchange. }\end{array}$ \\
\hline 7 & 31-Jan-18 & $20: 22$ & $\$ 0.9 \mathrm{~m}$ & BeeToken & $\begin{array}{l}\text { Cryptocurrency startup BeeToken was hacked while the } \\
\text { attackers targeted its ICO with phishing attacks. }\end{array}$ \\
\hline 8 & $05-$ Feb- 18 & $17: 00$ & $\$ 1.8 \mathrm{~m}$ & Ethereum & $\begin{array}{l}\text { Potential Seele ICO investors were scammed out of nearly } \\
\$ 2 \text { million by impersonators posing as administrators. }\end{array}$ \\
\hline 9 & 08-Feb-18 & $12: 00$ & $\$ 195.0 \mathrm{~m}$ & Nano & Exchange hack. \\
\hline 10 & $15-$ Feb- 18 & 09:00 & $\$ 50.0 \mathrm{~m}$ & Bitcoin & $\begin{array}{l}\text { A large scam had netted } \$ 50 \text { million in cryptocurrency } \\
\text { over a three-year period. }\end{array}$ \\
\hline 11 & 04-Mar-18 & $17: 41$ & $\$ 50.0 \mathrm{~m}$ & Bitcoin & $\begin{array}{l}\text { BTC Global was a scam launched in September } 2017 \text { by } \\
\text { 'famous' trader Steven Twain. }\end{array}$ \\
\hline 12 & 05-Apr-18 & $12: 00$ & $\$ 300.0 \mathrm{~m}$ & Bitcoin & $\begin{array}{l}\text { GainBitcoin began as a multi-level marketing (MLM) } \\
\text { scheme in } 2015 \text { and amassed over } 100,000 \text { investors, all } \\
\text { of whom were promised monthly returns of } 10 \% \text { on their } \\
\text { investment. }\end{array}$ \\
\hline 13 & 09-Apr-18 & 12:00 & $\$ 650.0 \mathrm{~m}$ & $\mathrm{ICO}$ & $\begin{array}{l}\text { Occurring in Vietnam, the largest alleged scam connected } \\
\text { to an ICO has been pulled off by two blockchain firms, } \\
\text { Ifan and Pincoin. }\end{array}$ \\
\hline 14 & 19-Apr-18 & 09:00 & $\$ 20.0 \mathrm{~m}$ & Bitcoin & $\begin{array}{l}\text { Two men started the scheme in } 2015 \text { and subsequently } \\
\text { built a multi-level company by promising investors high } \\
\text { returns through investing in bitcoin. " }\end{array}$ \\
\hline 15 & 10-Jun-18 & $17: 00$ & $\$ 40.0 \mathrm{~m}$ & NPXS & $\begin{array}{l}\text { Coinrail stated that it had suspended services after ERC- } \\
20 \text { based tokens were stolen from the platform. }\end{array}$ \\
\hline 16 & 16-Jun-18 & $07: 33$ & $\$ 31.5 \mathrm{~m}$ & Ethereum & $\begin{array}{l}\text { Bithumb moved a large amount of Ethereum to its cold } \\
\text { wallet when they recently noticed abnormal access. }\end{array}$ \\
\hline 17 & 09-Jul-18 & $21: 35$ & $\$ 23.5 \mathrm{~m}$ & Ethereum & $\begin{array}{l}\text { Bancor experienced a security breach to the hot wallet } \\
\text { used to update smart contracts on its exchange, result- } \\
\text { ing in a loss of approximately } \$ 23.5 \text { million worth of } \\
\text { Ethereum. }\end{array}$ \\
\hline
\end{tabular}

In the above table we have established a list of seventeen of the largest cryptocurrency hacking events between September 2017 and August 2018. 
Table 3: Multivariate GARCH methodology analysing cryptocurrency response to hacking events

\begin{tabular}{|c|c|c|c|c|c|c|c|c|}
\hline Variable & Bitcoin & Ethereum & Litecoin & Ripple & Stellar & Monero & Bit. Cash & Cardano \\
\hline$R_{1}$ & $\begin{array}{c}-0.1896^{* * *} \\
(-4.21)\end{array}$ & $\begin{array}{c}-0.0447 \\
(-1.74)\end{array}$ & $\begin{array}{c}-0.0558^{* *} \\
-2.39\end{array}$ & $\begin{array}{c}-0.1736^{* * *} \\
-8.44\end{array}$ & $\begin{array}{c}-0.2628^{* * * *} \\
-6.48\end{array}$ & $\begin{array}{c}-0.1499^{* * *} \\
-5.06\end{array}$ & $\begin{array}{c}-0.0060 \\
-0.27\end{array}$ & $\begin{array}{c}-0.2760^{* * *} \\
-8.84\end{array}$ \\
\hline$R_{2}$ & $\begin{array}{c}-0.0488 \\
(-1.57)\end{array}$ & $\begin{array}{c}-0.0131 \\
(-0.62)\end{array}$ & $\begin{array}{c}-0.0727 * * * \\
-3.67\end{array}$ & $\begin{array}{c}-0.2037^{* * *} \\
-10.14\end{array}$ & $\begin{array}{c}0.0345 \\
1.17\end{array}$ & $\begin{array}{c}-0.0137 \\
-0.44\end{array}$ & $\begin{array}{c}-0.0504^{* *} \\
-2.11\end{array}$ & $\begin{array}{c}-0.0709^{*} \\
-1.72\end{array}$ \\
\hline$R_{3}$ & $\begin{array}{c}0.0460 \\
(1.52)\end{array}$ & $\begin{array}{c}-0.0059 \\
(-0.24)\end{array}$ & $\begin{array}{c}-0.0472^{*} \\
-1.91\end{array}$ & $\begin{array}{c}0.0579^{* *} \\
2.44\end{array}$ & $\begin{array}{c}-0.1813^{* * *} \\
-11.08\end{array}$ & $\begin{array}{c}0.0774^{* * *} \\
2.86\end{array}$ & $\begin{array}{c}-0.0216 \\
-0.88\end{array}$ & $\begin{array}{c}0.0761^{* *} \\
2.11\end{array}$ \\
\hline$R_{4}$ & $\begin{array}{c}-0.0930^{* * *} \\
(-3.34)\end{array}$ & $\begin{array}{c}-0.0168 \\
(-0.86)\end{array}$ & $\begin{array}{c}-0.0656^{* * *} \\
-4.02\end{array}$ & $\begin{array}{c}-0.0092 \\
-0.40\end{array}$ & $\begin{array}{c}-0.0393^{*} \\
-1.78\end{array}$ & $\begin{array}{c}-0.0192 \\
-0.74\end{array}$ & $\begin{array}{c}-0.0063 \\
-0.25\end{array}$ & $\begin{array}{c}-0.0828^{* * *} \\
-3.03\end{array}$ \\
\hline$R_{5}$ & $\begin{array}{c}-0.0103 \\
(-0.42)\end{array}$ & $\begin{array}{c}-0.0192 \\
(-0.95)\end{array}$ & $\begin{array}{c}-0.0283 \\
-1.43\end{array}$ & $\begin{array}{c}-0.0217 \\
-0.98\end{array}$ & $\begin{array}{c}-0.1823^{* * *} \\
-9.04\end{array}$ & $\begin{array}{c}-0.0653^{* *} \\
-2.40\end{array}$ & $\begin{array}{c}-0.0341 \\
-1.62\end{array}$ & $\begin{array}{l}-0.0078 \\
-0.25\end{array}$ \\
\hline GBP/USD & $\begin{array}{c}0.2395 \\
(0.38)\end{array}$ & $\begin{array}{c}-0.4719 \\
(-1.23)\end{array}$ & $\begin{array}{c}0.2629 \\
0.52\end{array}$ & $\begin{array}{c}0.7008 \\
0.75\end{array}$ & $\begin{array}{c}-0.2349 * * * \\
-3.89\end{array}$ & $\begin{array}{c}0.0365 \\
0.05\end{array}$ & $\begin{array}{c}-0.7563 \\
-1.00\end{array}$ & $\begin{array}{c}-0.1159 \\
-0.09\end{array}$ \\
\hline VIX & $\begin{array}{c}0.0152 \\
(0.88)\end{array}$ & $\begin{array}{c}-0.0122 \\
(-0.75)\end{array}$ & $\begin{array}{c}-0.0177 \\
-1.00\end{array}$ & $\begin{array}{c}0.0141 \\
0.61\end{array}$ & $\begin{array}{c}0.0191 \\
0.88\end{array}$ & $\begin{array}{c}0.0153 \\
0.92\end{array}$ & $\begin{array}{c}0.0109 \\
0.48\end{array}$ & $\begin{array}{c}0.0237 \\
0.96\end{array}$ \\
\hline Gold & $\begin{array}{c}0.2286 \\
(0.67)\end{array}$ & $\begin{array}{c}-0.1741 \\
(-0.68)\end{array}$ & $\begin{array}{c}-0.0458 \\
-0.20\end{array}$ & $\begin{array}{c}0.3451 \\
0.83\end{array}$ & $\begin{array}{c}-0.5614^{*} \\
-1.78\end{array}$ & $\begin{array}{c}-0.0373 \\
-0.11\end{array}$ & $\begin{array}{c}-0.6397^{*} \\
-1.91\end{array}$ & $\begin{array}{c}0.0896 \\
0.16\end{array}$ \\
\hline S\&P500 & $\begin{array}{c}0.1595 \\
(0.56)\end{array}$ & $\begin{array}{c}0.0130 \\
(0.06)\end{array}$ & $\begin{array}{c}0.2417 \\
1.01\end{array}$ & $\begin{array}{c}0.4752 \\
1.24\end{array}$ & $\begin{array}{c}0.1625 \\
0.56\end{array}$ & $\begin{array}{c}0.1028 \\
0.36\end{array}$ & $\begin{array}{c}-0.0808 \\
-0.23\end{array}$ & $\begin{array}{c}0.1235 \\
0.39\end{array}$ \\
\hline Oil & $\begin{array}{c}-0.1174 \\
(-1.04)\end{array}$ & $\begin{array}{c}-0.0506 \\
(-0.60)\end{array}$ & $\begin{array}{c}-0.0124 \\
-0.16\end{array}$ & $\begin{array}{c}-0.1537 \\
-1.08\end{array}$ & $\begin{array}{c}-0.2540^{*} \\
-1.71\end{array}$ & $\begin{array}{c}0.1124 \\
0.90\end{array}$ & $\begin{array}{c}0.1365 \\
0.96\end{array}$ & $\begin{array}{c}0.3203^{*} \\
1.73\end{array}$ \\
\hline$D_{1}$ & $\begin{array}{c}-0.0011 \\
(-1.60)\end{array}$ & $\begin{array}{c}0.0010 \\
(0.92)\end{array}$ & $\begin{array}{c}0.0016 \\
1.22\end{array}$ & $\begin{array}{c}0.0007 \\
0.42\end{array}$ & $\begin{array}{c}0.0011 \\
0.38\end{array}$ & $\begin{array}{c}0.0030^{*} \\
1.90\end{array}$ & $\begin{array}{c}0.0023 \\
1.53\end{array}$ & $\begin{array}{c}0.0019 \\
1.54\end{array}$ \\
\hline$D_{2}$ & $\begin{array}{c}-0.0005 \\
(-0.67)\end{array}$ & $\begin{array}{c}-0.0015^{* * *} \\
(-4.19)\end{array}$ & $\begin{array}{c}-0.0006 \\
-0.63\end{array}$ & $\begin{array}{c}-0.0012 \\
-1.20\end{array}$ & $\begin{array}{c}0.0016 \\
0.43\end{array}$ & $\begin{array}{c}-0.0003 \\
-0.27\end{array}$ & $\begin{array}{c}0.0002 \\
0.12\end{array}$ & $\begin{array}{c}-0.0004 \\
-0.43\end{array}$ \\
\hline$D_{3}$ & $\begin{array}{c}0.0033^{* * *} \\
(2.89)\end{array}$ & $\begin{array}{c}-0.0021 * * * \\
(-2.54)\end{array}$ & $\begin{array}{c}-0.0013 \\
-1.32\end{array}$ & $\begin{array}{c}0.0008 \\
1.02\end{array}$ & $\begin{array}{c}0.0002 \\
0.04\end{array}$ & $\begin{array}{c}-0.0003 \\
-0.18\end{array}$ & $\begin{array}{c}-0.0010 \\
-0.70\end{array}$ & $\begin{array}{c}0.0003 \\
0.13\end{array}$ \\
\hline$D_{4}$ & $\begin{array}{c}-0.0031^{* * *} \\
(-2.62)\end{array}$ & $\begin{array}{c}-0.0016 \\
(-1.59)\end{array}$ & $\begin{array}{c}-0.0010 \\
-0.49\end{array}$ & $\begin{array}{c}0.0023 \\
1.43\end{array}$ & $\begin{array}{c}0.0053^{* * *} \\
2.59\end{array}$ & $\begin{array}{c}-0.0068^{* * *} \\
-6.52\end{array}$ & $\begin{array}{c}-0.0051^{* *} \\
-2.38\end{array}$ & $\begin{array}{c}-0.0002 \\
-0.16\end{array}$ \\
\hline$D_{5}$ & $\begin{array}{c}-0.0020^{*} \\
(-1.69)\end{array}$ & $\begin{array}{c}-0.0013 \\
(-1.02)\end{array}$ & $\begin{array}{c}-0.0019 \\
-1.33\end{array}$ & $\begin{array}{c}-0.0033^{*} \\
-1.68\end{array}$ & $\begin{array}{c}-0.0016 \\
-0.83\end{array}$ & $\begin{array}{c}-0.0009 \\
-0.50\end{array}$ & $\begin{array}{c}-0.0030^{*} \\
-1.90\end{array}$ & $\begin{array}{c}-0.0009 \\
-0.60\end{array}$ \\
\hline$D_{6}$ & $\begin{array}{c}-0.0010 \\
(-0.98)\end{array}$ & $\begin{array}{c}0.0005 \\
(0.50)\end{array}$ & $\begin{array}{c}-0.0001 \\
-0.13\end{array}$ & $\begin{array}{c}-0.0002 \\
-0.17\end{array}$ & $\begin{array}{c}-0.0011 \\
-1.13\end{array}$ & $\begin{array}{c}-0.0008 \\
-0.68\end{array}$ & $\begin{array}{c}-0.0003 \\
-0.23\end{array}$ & $\begin{array}{c}-0.0006 \\
-0.65\end{array}$ \\
\hline$D_{7}$ & $\begin{array}{c}-0.0008 \\
(-0.83)\end{array}$ & $\begin{array}{c}-0.0003 \\
(-0.27)\end{array}$ & $\begin{array}{c}0.0032^{* * *} \\
2.47\end{array}$ & $\begin{array}{c}0.0106^{* * *} \\
17.34\end{array}$ & $\begin{array}{c}0.0056^{* * *} \\
9.23\end{array}$ & $\begin{array}{c}-0.0011 \\
-0.76\end{array}$ & $\begin{array}{l}-0.0016 \\
-1.17\end{array}$ & $\begin{array}{c}0.0019^{* *} \\
2.41\end{array}$ \\
\hline$D_{8}$ & $\begin{array}{c}0.0025 \\
(1.37)\end{array}$ & $\begin{array}{c}0.0033^{*} \\
(1.91)\end{array}$ & $\begin{array}{c}0.0029 \\
1.38\end{array}$ & $\begin{array}{c}0.0042^{* * *} \\
2.49\end{array}$ & $\begin{array}{c}0.0010 \\
0.87\end{array}$ & $\begin{array}{c}0.0053^{* *} \\
2.31\end{array}$ & $\begin{array}{c}0.0054^{* *} \\
2.39\end{array}$ & $\begin{array}{c}0.0011 \\
0.90\end{array}$ \\
\hline$D_{9}$ & $\begin{array}{c}-0.0004 \\
(-0.26)\end{array}$ & $\begin{array}{c}-0.0008 \\
(-0.71)\end{array}$ & $\begin{array}{c}-0.0002 \\
-0.11\end{array}$ & $\begin{array}{c}0.0008 \\
0.39\end{array}$ & $\begin{array}{c}0.0000 \\
0.05\end{array}$ & $\begin{array}{c}-0.0013 \\
-0.69\end{array}$ & $\begin{array}{c}-0.0009 \\
-0.44\end{array}$ & $\begin{array}{c}-0.0006 \\
-0.50\end{array}$ \\
\hline$D_{10}$ & $\begin{array}{c}0.0008 \\
(0.87)\end{array}$ & $\begin{array}{c}0.0003 \\
(0.29)\end{array}$ & $\begin{array}{c}-0.0003 \\
-0.19\end{array}$ & $\begin{array}{c}0.0020^{* * *} \\
2.77\end{array}$ & $\begin{array}{c}-0.0004 \\
-0.44\end{array}$ & $\begin{array}{c}0.0021 \\
1.61\end{array}$ & $\begin{array}{c}0.0028^{* * *} \\
2.75\end{array}$ & $\begin{array}{c}-0.0002 \\
-0.44\end{array}$ \\
\hline$D_{11}$ & $\begin{array}{c}-0.0027^{* * *} \\
(-6.74)\end{array}$ & $\begin{array}{c}-0.0018^{* *} \\
(-2.33)\end{array}$ & $\begin{array}{c}-0.0012 \\
-1.41\end{array}$ & $\begin{array}{c}-0.0041^{* * *} \\
-4.72\end{array}$ & $\begin{array}{c}0.0017^{* *} \\
2.50\end{array}$ & $\begin{array}{c}-0.0028^{* * *} \\
-3.18\end{array}$ & $\begin{array}{c}-0.0020^{* *} \\
-2.09\end{array}$ & $\begin{array}{c}-0.0010 \\
-0.98\end{array}$ \\
\hline$D_{12}$ & $\begin{array}{c}-0.0005 \\
(-0.86)\end{array}$ & $\begin{array}{c}0.0010 \\
(0.99)\end{array}$ & $\begin{array}{c}0.0000 \\
0.00\end{array}$ & $\begin{array}{c}0.0001 \\
0.05\end{array}$ & $\begin{array}{c}0.0002 \\
0.31\end{array}$ & $\begin{array}{c}-0.0005 \\
-0.62\end{array}$ & $\begin{array}{c}-0.0002 \\
-0.19\end{array}$ & $\begin{array}{c}0.0009 \\
1.08\end{array}$ \\
\hline$D_{13}$ & $\begin{array}{c}0.0091^{* * *} \\
(4.52)\end{array}$ & $\begin{array}{c}0.0017^{*} \\
(1.65)\end{array}$ & $\begin{array}{c}0.0009 \\
0.95\end{array}$ & $\begin{array}{c}0.0013 \\
0.67\end{array}$ & $\begin{array}{c}0.0011 \\
1.19\end{array}$ & $\begin{array}{c}0.0010 \\
0.81\end{array}$ & $\begin{array}{c}0.0016 \\
1.27\end{array}$ & $\begin{array}{c}0.0008 \\
1.50\end{array}$ \\
\hline$D_{14}$ & $\begin{array}{c}0.0008 \\
(1.13)\end{array}$ & $\begin{array}{c}0.0020^{*} \\
(1.91)\end{array}$ & $\begin{array}{c}0.0011 \\
1.08\end{array}$ & $\begin{array}{c}0.0018 \\
1.22\end{array}$ & $\begin{array}{c}0.0000 \\
-0.03\end{array}$ & $\begin{array}{c}0.0027^{* *} \\
2.12\end{array}$ & $\begin{array}{c}0.0065^{* * *} \\
5.19\end{array}$ & $\begin{array}{c}0.0000 \\
-0.01\end{array}$ \\
\hline$D_{15}$ & $\begin{array}{c}-0.0023^{* * *} \\
(-4.68)\end{array}$ & $\begin{array}{c}-0.0021^{* *} \\
(-2.36)\end{array}$ & $\begin{array}{c}-0.0023^{* *} \\
-2.63\end{array}$ & $\begin{array}{l}-0.0008 \\
-0.50\end{array}$ & $\begin{array}{c}0.0001 \\
0.10\end{array}$ & $\begin{array}{c}-0.0053^{* * *} \\
-8.39\end{array}$ & $\begin{array}{l}-0.0015 \\
-1.04\end{array}$ & $\begin{array}{c}0.0016^{* * *} \\
2.68\end{array}$ \\
\hline$D_{16}$ & $\begin{array}{c}0.0002 \\
(0.25)\end{array}$ & $\begin{array}{c}0.0004 \\
(0.50)\end{array}$ & $\begin{array}{c}0.0002 \\
0.25\end{array}$ & $\begin{array}{c}-0.0001 \\
-0.09\end{array}$ & $\begin{array}{c}0.0000 \\
-0.07\end{array}$ & $\begin{array}{c}0.0000 \\
0.03\end{array}$ & $\begin{array}{c}0.0001 \\
0.08\end{array}$ & $\begin{array}{c}-0.0003 \\
-0.50\end{array}$ \\
\hline$D_{17}$ & $\begin{array}{c}-0.0009 \\
(-1.17)\end{array}$ & $\begin{array}{c}-0.0007 \\
(-0.67)\end{array}$ & $\begin{array}{c}-0.0003 \\
-0.28\end{array}$ & $\begin{array}{c}-0.0008 \\
-0.39\end{array}$ & $\begin{array}{c}0.0099 * * * \\
50.18\end{array}$ & $\begin{array}{c}-0.0013 \\
-1.08\end{array}$ & $\begin{array}{c}-0.0007 \\
-0.42\end{array}$ & $\begin{array}{c}0.0101 * * * \\
52.61\end{array}$ \\
\hline $\mathrm{ARCH}$ & $\begin{array}{c}0.0600 * * * \\
(38.31)\end{array}$ & $\begin{array}{c}0.1160 * * * \\
(27.26)\end{array}$ & $\begin{array}{c}0.1122^{* * *} \\
33.59\end{array}$ & $\begin{array}{c}0.1922^{* * *} \\
44.28\end{array}$ & $\begin{array}{c}0.1039 * * * \\
50.27\end{array}$ & $\begin{array}{c}0.0882^{* * *} \\
26.06\end{array}$ & $\begin{array}{c}0.0960^{* * *} \\
28.32\end{array}$ & $\begin{array}{c}0.1693^{* * *} \\
36.53\end{array}$ \\
\hline GARCH & $\begin{array}{c}0.9287^{* * *} * \\
(547.03)\end{array}$ & $\begin{array}{c}0.8457^{* * *} \\
(166.53)\end{array}$ & $\begin{array}{c}0.8682^{* * *} \\
244.46\end{array}$ & $\begin{array}{c}0.7401^{* * * *} \\
126.58\end{array}$ & $\begin{array}{c}0.8927^{* * * *} \\
447.46\end{array}$ & $\begin{array}{c}0.9025^{* * *} \\
265.69\end{array}$ & $\begin{array}{c}0.8803^{* * *} \\
211.51\end{array}$ & $\begin{array}{c}0.8273^{* * *} \\
207.79\end{array}$ \\
\hline
\end{tabular}

T-statistics are in parentheses. $*, * *$ and $* * *$ indicate significance at the $10 \%, 5 \%$ and $1 \%$ levels, respectively. 
Table 4: Multivariate GARCH methodology using a continuous variable representing cryptocurrency cybercriminality

\begin{tabular}{|c|c|c|c|c|c|c|c|c|}
\hline Variable & Bitcoin & Ethereum & Litecoin & Ripple & Stellar & Monero & Bit. Cash & Cardano \\
\hline GBP/USD & $\begin{array}{c}0.2603 \\
(0.48)\end{array}$ & $\begin{array}{c}-0.4136 \\
(-1.08)\end{array}$ & $\begin{array}{c}0.1857 \\
(0.38)\end{array}$ & $\begin{array}{c}0.7232 \\
(0.80)\end{array}$ & $\begin{array}{c}-0.3563^{* * *} \\
(-6.40)\end{array}$ & $\begin{array}{c}-0.0840 \\
(-0.11)\end{array}$ & $\begin{array}{c}-0.6414 \\
(-0.86)\end{array}$ & $\begin{array}{c}-0.1867 \\
(-0.14)\end{array}$ \\
\hline VIX & $\begin{array}{c}0.0243 \\
(1.36)\end{array}$ & $\begin{array}{c}-0.0121 \\
(-0.74)\end{array}$ & $\begin{array}{c}-0.0087 \\
(-0.45)\end{array}$ & $\begin{array}{c}0.0406 \\
(1.45)\end{array}$ & $\begin{array}{c}0.0246 \\
(1.03)\end{array}$ & $\begin{array}{c}0.0019 \\
(0.09)\end{array}$ & $\begin{array}{c}0.0196 \\
(0.89)\end{array}$ & $\begin{array}{c}0.0224 \\
(0.68)\end{array}$ \\
\hline Gold & $\begin{array}{c}0.3161 \\
(1.17)\end{array}$ & $\begin{array}{c}-0.1161 \\
(-0.50)\end{array}$ & $\begin{array}{c}-0.1151 \\
(-0.64)\end{array}$ & $\begin{array}{c}0.1236 \\
(0.30)\end{array}$ & $\begin{array}{c}-1.6722^{* * *} \\
(-4.82)\end{array}$ & $\begin{array}{c}-0.0055 \\
(-0.02)\end{array}$ & $\begin{array}{c}-0.6468 * * \\
(-2.01)\end{array}$ & $\begin{array}{c}-0.1227 \\
(-0.19)\end{array}$ \\
\hline S\&P500 & $\begin{array}{c}0.1495 \\
(0.52)\end{array}$ & $\begin{array}{c}0.0204 \\
(0.10)\end{array}$ & $\begin{array}{c}0.2712 \\
(1.02)\end{array}$ & $\begin{array}{c}0.3528 \\
(0.94)\end{array}$ & $\begin{array}{c}0.1936 \\
(0.64)\end{array}$ & $\begin{array}{c}0.1635 \\
(0.47)\end{array}$ & $\begin{array}{c}0.0368 \\
(0.10)\end{array}$ & $\begin{array}{c}0.3369 \\
(0.94)\end{array}$ \\
\hline Oil & $\begin{array}{r}-0.0817 \\
(-0.79)\end{array}$ & $\begin{array}{c}-0.0510 \\
(-0.63)\end{array}$ & $\begin{array}{c}0.0233 \\
(0.31)\end{array}$ & $\begin{array}{c}0.1251 \\
(0.73)\end{array}$ & $\begin{array}{c}-0.3224^{* * *} * \\
(-1.89)\end{array}$ & $\begin{array}{r}0.0667 \\
(0.45)\end{array}$ & $\begin{array}{c}0.1202 \\
(0.86)\end{array}$ & $\begin{array}{c}0.0385 \\
(0.28)\end{array}$ \\
\hline Volatility Change & $\begin{array}{c}1.3916^{* * *} \\
(5.22)\end{array}$ & $\begin{array}{c}0.4297 \\
(0.66)\end{array}$ & $\begin{array}{c}1.2624^{* * * *} \\
(3.40)\end{array}$ & $\begin{array}{c}3.2872^{* *} \\
(2.29)\end{array}$ & $\begin{array}{c}1.2265^{*} \\
(1.87)\end{array}$ & $\begin{array}{c}1.4947^{* * * *} \\
(8.82)\end{array}$ & $\begin{array}{c}0.8512 \\
(1.52)\end{array}$ & $\begin{array}{c}0.7668 \\
(0.15)\end{array}$ \\
\hline $\mathrm{ARCH}$ & $\begin{array}{c}0.2924^{* * *} \\
\quad(4.35)\end{array}$ & $\begin{array}{c}0.1879 * * * \\
(8.15)\end{array}$ & $\begin{array}{c}0.2309^{* * *} \\
(7.32)\end{array}$ & $\begin{array}{c}0.4030^{* * *} \\
(18.43)\end{array}$ & $\begin{array}{c}0.2846^{* * * *} \\
(8.55)\end{array}$ & $\begin{array}{c}0.2607^{* * *} * \\
(2.64)\end{array}$ & $\begin{array}{c}0.3532 * * * \\
\quad(7.79)\end{array}$ & $\begin{array}{c}0.4629^{* * *} \\
\quad(6.13)\end{array}$ \\
\hline GARCH & $\begin{array}{c}0.5062^{* * *} \\
(7.50)\end{array}$ & $\begin{array}{c}0.7866^{* * *} \\
(9.84)\end{array}$ & $\begin{array}{c}0.7598^{* * *} \\
(10.92)\end{array}$ & $\begin{array}{c}0.5845^{* * *} \\
(13.91)\end{array}$ & $\begin{array}{c}0.9218^{* * *} \\
(13.75)\end{array}$ & $\begin{array}{c}0.4477^{* * *} \\
(4.42)\end{array}$ & $\begin{array}{c}0.6280^{* * *} \\
(7.54)\end{array}$ & $\begin{array}{c}0.5750^{* * *} \\
(10.45)\end{array}$ \\
\hline
\end{tabular}

T-statistics are in parentheses. ${ }^{*}, * *$ and $* * *$ indicate significance at the $10 \%, 5 \%$ and $1 \%$ levels, respectively. 
Table 5: Dynamic correlations between selected cryptocurrency markets during hacking events

\begin{tabular}{|c|c|c|c|c|c|c|c|c|c|c|c|c|c|}
\hline & ET-BT & LT-BT & RI-BT & ST-BT & MO-BT & $\mathrm{Bc}-\mathrm{BT}$ & LT-ET & RI-ET & ST-ET & MO-ET & Bc-ET & RI-LT & ST-LT \\
\hline Total & 0.01 & 0.02 & 0.01 & 0.00 & 0.01 & 0.01 & 0.02 & 0.02 & 0.01 & 0.02 & 0.01 & 0.02 & 0.01 \\
\hline$D_{1}$ & 0.01 & 0.02 & 0.01 & 0.01 & 0.01 & 0.01 & 0.02 & 0.01 & 0.00 & 0.01 & 0.02 & 0.02 & 0.00 \\
\hline$D_{2}$ & 0.00 & 0.01 & 0.00 & 0.00 & 0.00 & 0.00 & 0.01 & 0.01 & 0.00 & 0.00 & 0.00 & 0.01 & 0.00 \\
\hline$D_{3}$ & 0.01 & 0.02 & 0.01 & 0.01 & 0.04 & 0.01 & 0.02 & 0.01 & 0.02 & 0.04 & 0.02 & 0.01 & 0.03 \\
\hline$D_{4}$ & 0.16 & 0.25 & 0.19 & 0.05 & 0.17 & 0.12 & 0.24 & 0.20 & 0.07 & 0.16 & 0.13 & 0.33 & 0.13 \\
\hline$D_{5}$ & 0.10 & 0.13 & 0.13 & 0.07 & 0.10 & 0.11 & 0.14 & 0.17 & 0.07 & 0.10 & 0.12 & 0.19 & 0.11 \\
\hline$D_{6}$ & 0.02 & 0.02 & 0.02 & 0.00 & 0.02 & 0.02 & 0.01 & 0.02 & 0.00 & 0.02 & 0.02 & 0.02 & 0.00 \\
\hline$D_{7}$ & 0.04 & 0.06 & 0.04 & 0.02 & 0.04 & 0.03 & 0.06 & 0.05 & 0.02 & 0.04 & 0.03 & 0.07 & 0.04 \\
\hline$D_{8}$ & 0.02 & 0.02 & 0.03 & 0.00 & 0.02 & 0.02 & 0.02 & 0.03 & 0.00 & 0.02 & 0.02 & 0.03 & 0.00 \\
\hline$D_{9}$ & 0.02 & 0.02 & 0.03 & 0.01 & 0.02 & 0.02 & 0.02 & 0.03 & 0.01 & 0.02 & 0.02 & 0.03 & 0.01 \\
\hline$D_{10}$ & 0.01 & 0.01 & 0.01 & 0.00 & 0.01 & 0.01 & 0.01 & 0.01 & 0.00 & 0.01 & 0.01 & 0.01 & 0.00 \\
\hline$D_{11}$ & 0.03 & 0.03 & 0.02 & 0.00 & 0.03 & 0.03 & 0.02 & 0.02 & 0.00 & 0.03 & 0.02 & 0.02 & 0.00 \\
\hline$D_{12}$ & 0.02 & 0.02 & 0.02 & 0.00 & 0.02 & 0.02 & 0.02 & 0.02 & 0.01 & 0.02 & 0.02 & 0.02 & 0.00 \\
\hline$D_{13}$ & 0.02 & 0.02 & 0.02 & 0.00 & 0.02 & 0.02 & 0.02 & 0.03 & 0.00 & 0.02 & 0.02 & 0.03 & 0.00 \\
\hline$D_{14}$ & 0.01 & 0.00 & 0.00 & 0.00 & 0.01 & 0.01 & 0.01 & 0.01 & 0.00 & 0.01 & 0.01 & 0.01 & 0.00 \\
\hline$D_{15}$ & 0.01 & 0.01 & 0.01 & 0.00 & 0.01 & 0.01 & 0.01 & 0.01 & 0.01 & 0.02 & 0.01 & 0.01 & 0.01 \\
\hline$D_{16}$ & 0.01 & 0.00 & 0.01 & 0.00 & 0.01 & 0.01 & 0.01 & 0.01 & 0.00 & 0.01 & 0.01 & 0.01 & 0.00 \\
\hline$D_{17}$ & 0.00 & 0.00 & 0.01 & 0.00 & 0.01 & 0.00 & 0.01 & 0.01 & 0.00 & 0.01 & 0.01 & 0.01 & 0.00 \\
\hline & MO-LT & Bc-LT & CA-LT & ST-RI & MO-RI & Bc-RI & CA-RI & MO-ST & $\mathrm{Bc}-\mathrm{ST}$ & CA-ST & Bc-MO & CA-MO & $\mathrm{CA}-\mathrm{Bc}$ \\
\hline Total & 0.02 & 0.02 & 0.00 & 0.01 & $\begin{array}{l}0.02 \\
\end{array}$ & 0.01 & 0.01 & 0.01 & 0.00 & 0.01 & 0.02 & 0.01 & 0.00 \\
\hline$D_{1}$ & 0.01 & 0.03 & 0.00 & 0.00 & 0.00 & 0.01 & 0.00 & 0.01 & -0.02 & 0.01 & 0.00 & 0.00 & 0.02 \\
\hline$D_{2}$ & 0.00 & 0.00 & 0.00 & 0.00 & 0.00 & 0.00 & 0.00 & 0.01 & 0.00 & 0.01 & 0.01 & 0.00 & 0.00 \\
\hline$D_{3}$ & 0.05 & 0.04 & 0.02 & 0.01 & 0.02 & 0.01 & 0.01 & 0.05 & 0.04 & 0.06 & 0.05 & 0.02 & 0.02 \\
\hline$D_{4}$ & 0.25 & 0.18 & 0.05 & 0.17 & 0.19 & 0.12 & 0.06 & 0.08 & 0.04 & 0.06 & 0.17 & 0.02 & 0.02 \\
\hline$D_{5}$ & 0.14 & 0.16 & 0.03 & 0.11 & 0.10 & 0.13 & 0.04 & 0.09 & 0.10 & 0.04 & 0.15 & 0.03 & 0.03 \\
\hline$D_{6}$ & 0.02 & 0.02 & 0.00 & 0.00 & 0.02 & 0.02 & 0.00 & 0.00 & 0.00 & 0.00 & 0.02 & 0.00 & 0.00 \\
\hline$D_{7}$ & 0.06 & 0.05 & 0.04 & 0.03 & 0.04 & 0.03 & 0.03 & 0.02 & 0.02 & 0.02 & 0.03 & 0.02 & 0.02 \\
\hline$D_{8}$ & 0.02 & 0.02 & 0.00 & 0.01 & 0.03 & 0.02 & 0.01 & 0.00 & 0.00 & 0.01 & 0.02 & 0.00 & 0.00 \\
\hline$D_{9}$ & 0.02 & 0.02 & 0.00 & 0.01 & 0.03 & 0.02 & 0.01 & 0.01 & 0.00 & 0.00 & 0.02 & 0.00 & 0.00 \\
\hline$D_{10}$ & 0.01 & 0.01 & 0.00 & 0.00 & 0.01 & 0.01 & 0.00 & 0.00 & 0.00 & 0.00 & 0.01 & 0.00 & 0.00 \\
\hline$D_{11}$ & 0.02 & 0.02 & 0.00 & 0.00 & 0.02 & 0.02 & 0.00 & 0.00 & 0.00 & 0.00 & 0.03 & 0.00 & 0.00 \\
\hline$D_{12}$ & 0.01 & 0.02 & 0.00 & 0.01 & 0.02 & 0.02 & 0.00 & 0.00 & 0.01 & 0.00 & 0.02 & 0.00 & 0.00 \\
\hline$D_{13}$ & 0.02 & 0.02 & 0.00 & 0.01 & 0.03 & 0.03 & 0.01 & 0.00 & 0.00 & 0.01 & 0.02 & 0.00 & 0.00 \\
\hline$D_{14}$ & 0.01 & 0.01 & 0.00 & 0.00 & 0.01 & 0.01 & 0.00 & 0.00 & 0.00 & 0.00 & 0.01 & 0.00 & 0.01 \\
\hline$D_{15}$ & 0.02 & 0.01 & 0.01 & 0.01 & 0.02 & 0.01 & 0.01 & 0.01 & 0.01 & 0.01 & 0.02 & 0.02 & 0.01 \\
\hline$D_{16}$ & 0.01 & 0.01 & 0.00 & 0.00 & 0.01 & 0.01 & 0.00 & 0.00 & 0.00 & 0.00 & 0.01 & 0.00 & 0.00 \\
\hline$D_{17}$ & 0.01 & 0.01 & 0.00 & 0.00 & 0.01 & 0.01 & 0.01 & 0.01 & 0.00 & 0.12 & 0.00 & 0.01 & 0.01 \\
\hline
\end{tabular}

Note: Results are scaled for presentation purposes by multiplying original coefficients by $10^{2}$. For brevity we have only included selected abnormal return results. All other results related to the abnormal returns of cryptocurrencies due to hacking events are available from the authors on request. 
Figure 1: Selected dynamic correlations between cryptocurrencies during cybercrime events
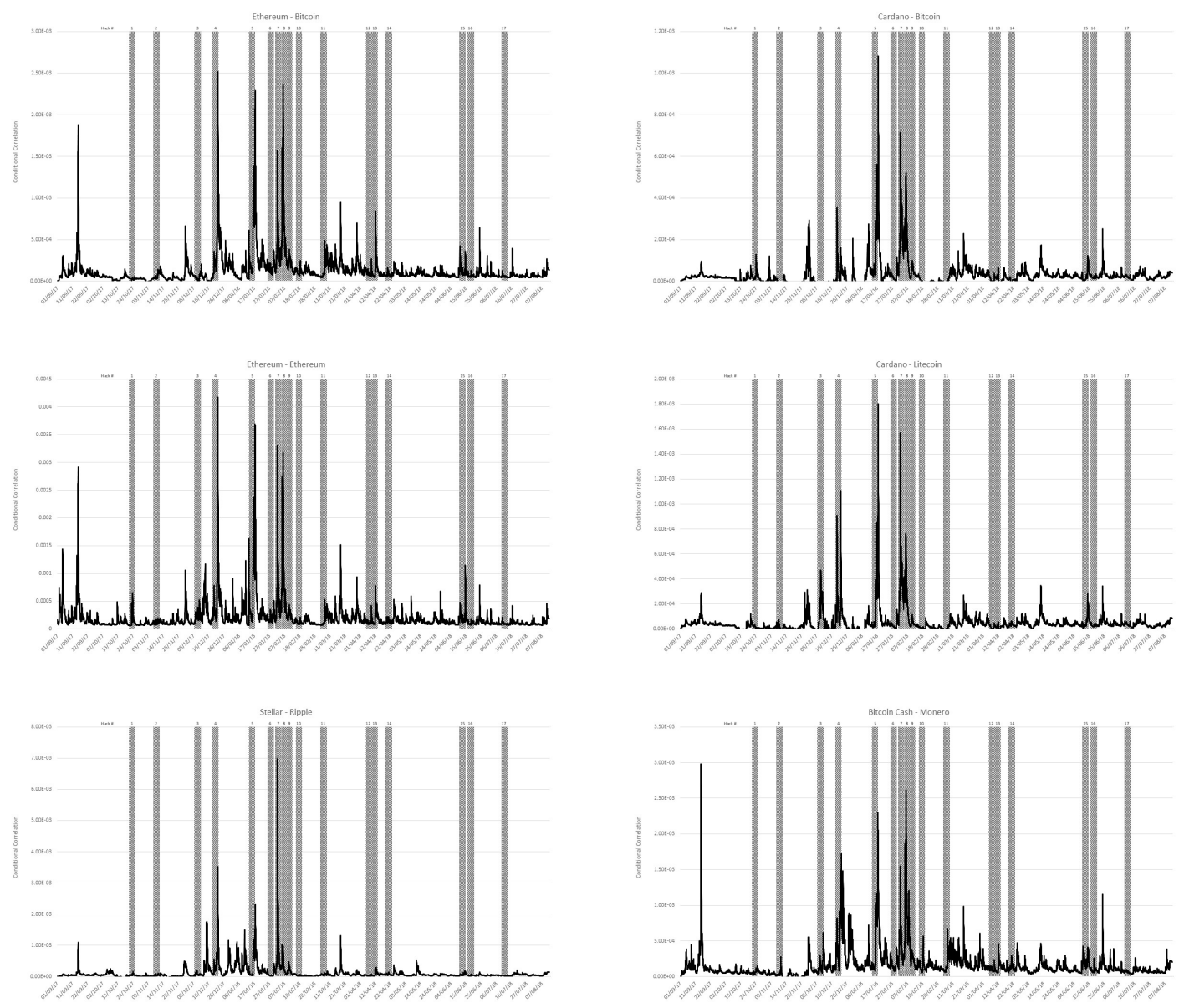

Note: For brevity we have only included selected dynamic correlation results. All other results related to the abnormal returns of cryptocurrencies due to hacking events are available from the authors on request. 
Figure 2: Change in Information Share (IS) between cryptocurrencies in the period after a hacking event

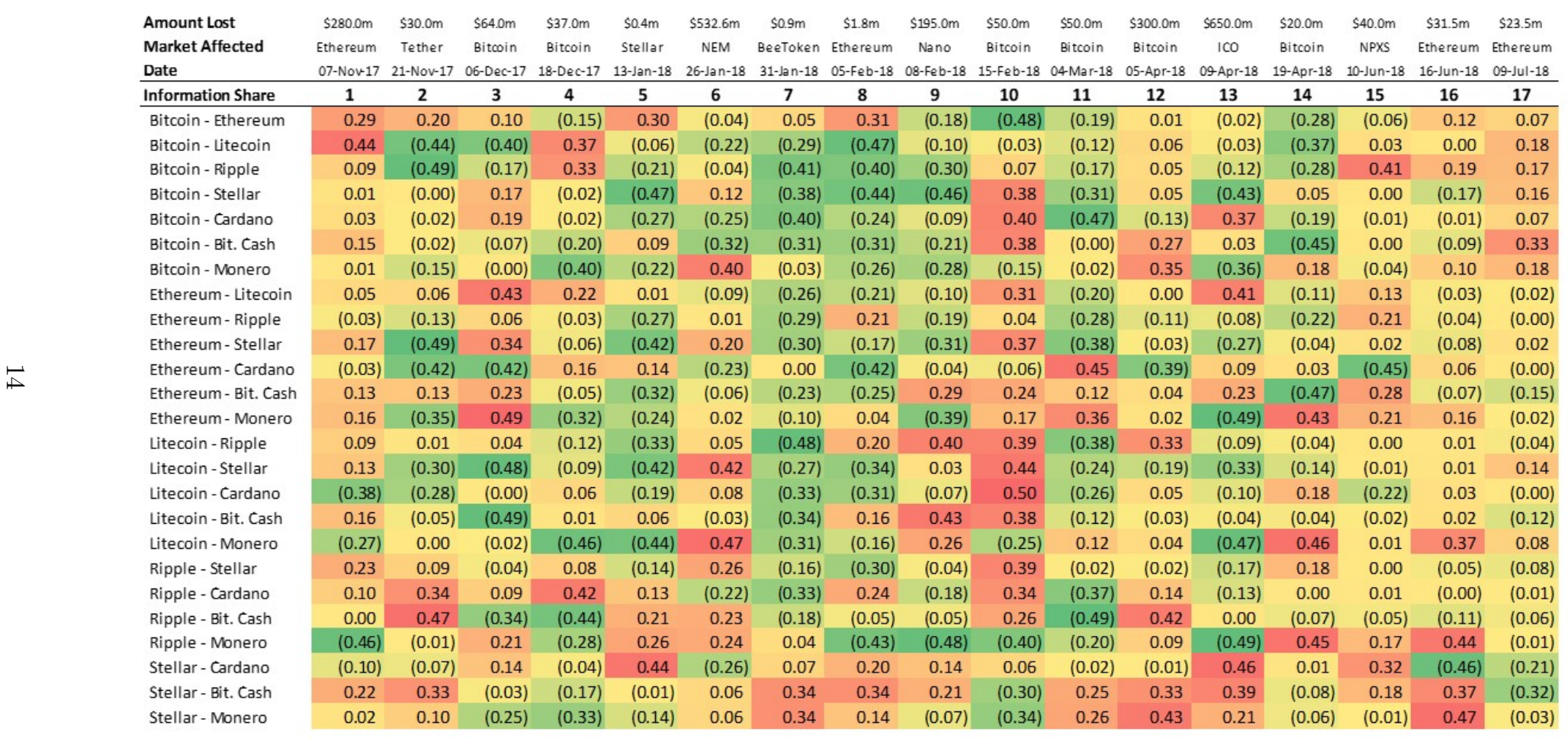


Figure 3: Change in Information Leadership Share (ILS) between cryptocurrencies in the period after a hacking event

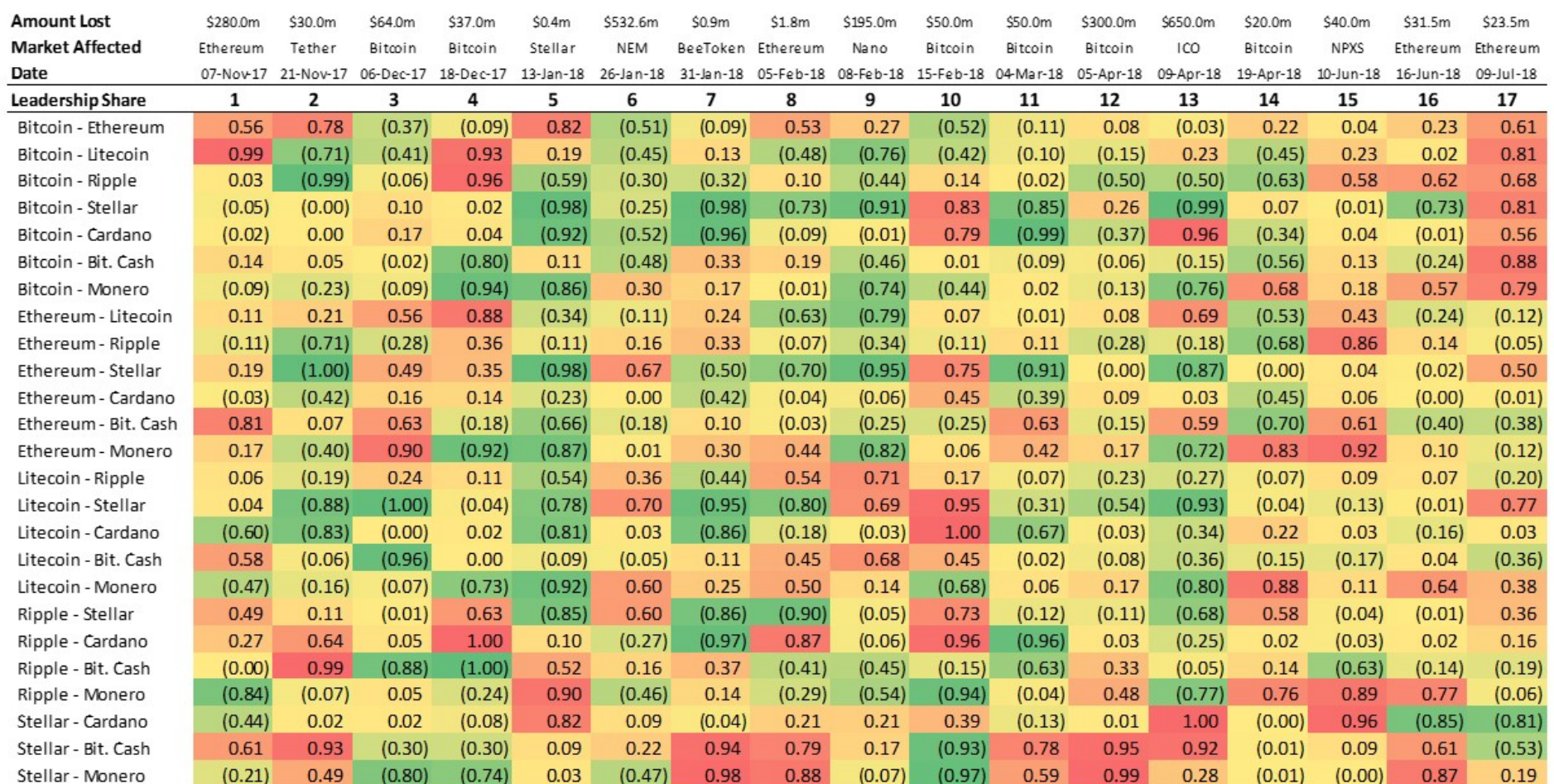


Figure 4: Abnormal cryptocurrency returns in the period after each denoted hacking event

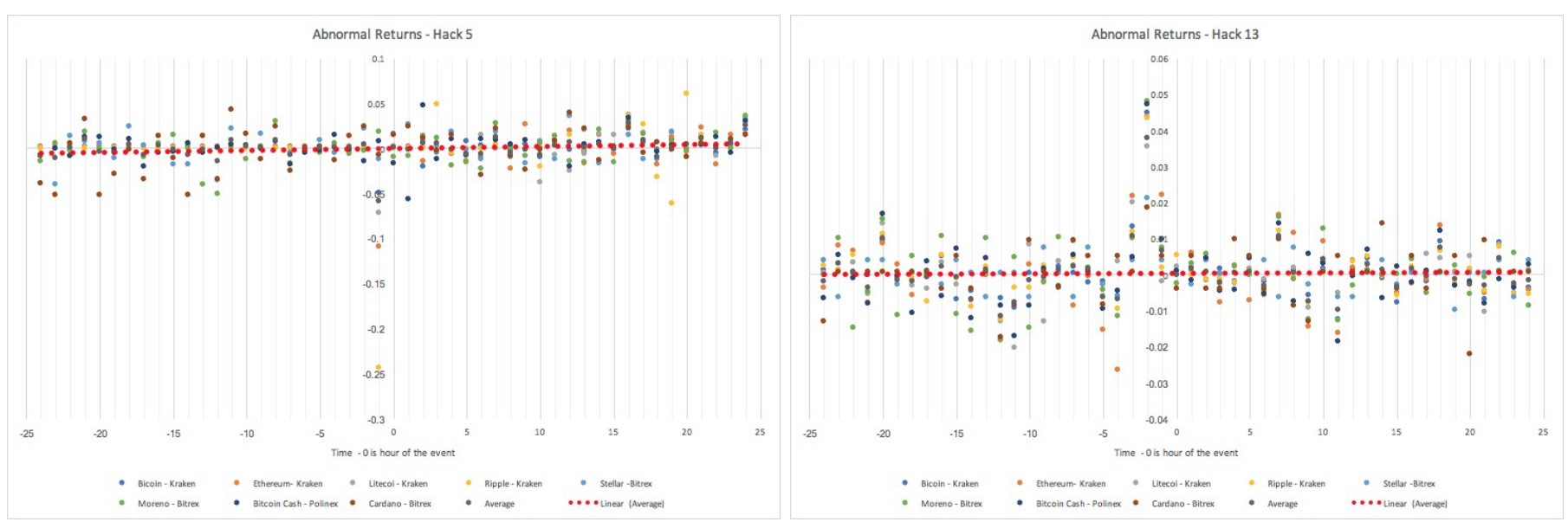

Note: The above figure represents the abnormal returns of our selected cryptocurrencies during the 24 hours periods both before and after major cryptocurrency hacking events. For brevity we have only included selected abnormal return results. All other results related to the abnormal returns of cryptocurrencies due to hacking events are available from the authors on request. 